Дергачова В.B. доктор. економ. наук, професор ORCID ID: 0000-0003-0317-8675

Згуровський О.М.

канд. економ. наук ORCID ID: 0000-0001-7539-9907

Чорній В.В

канд. економ. наук ORCID ID: 0000-0002-4460-0759 Національний технічний університет України «Київський політехнічний інститут імені Ігоря Сікорського»

\title{
АКУМУЛЮВАННЯ ТА ПЕРЕРОЗПОДІЛ ІНВЕСТИЦЙНИХ РЕСУРСІВ НА РИНКУ ЦІННИ ПАПЕРІВ В УМОВАХ ЦИКЛІЧНОГО РОЗВИТКУ ЕКОНОМІКИ
}

\author{
АККУМУЛИРОВАНИЕ И ПЕРЕРАСПРЕДЕЛЕНИЕ ИНВЕСТИЦИОННЫХ \\ РЕСУРСОВ НА РЫНКЕ ЦЕННЫХ БУМАГ В УСЛОВИЯХ ЦИКЛИЧЕСКОГО \\ РАЗВИТИЯ ЭКОНОМИКИ
}

\section{ACCUMULATION AND REDISTRIBUTION OF INVESTMENT RESOURCES ON THE SECURITIES MARKET IN CONDITIONS OF CYCLICAL ECONOMIC DEVELOPMENT}

Циклічність розвитку начіональної економіки України чітко простежується протягом років ї̈ незалежності за основними макроекономічними показниками. У статті досліджено тенденції акумулювання та перерозподілу інвестиційних ресурсів на ринку цінних паперів в умовах циклічності розвитку економіки. Досвід розвинутих країн підтверджує, щзо за умов відсутності сприятливого інвестиційного клімату, чіткої структури суб'єктів i інструментів інвестування, належних кількісних та якісних показників господарської діяльності об’єктів інвестування неможливо досягти потрібного рівня активності інвестиційних процесів.

Виявлено особливості розвитку світового фондового ринку та ринку України; для ефективного функціонування ринку цінних паперів в сучасних умовах існує проблема недостатнього рівня ринкової капіталізації підприємств реального сектора національної економіки, потениійно відкритої для інвестування.

Проаналізовано стану $і$ розвитку прочесів інвестування підприємств газової промисловості Украӥни. Виявлено, щуо в умовах глобалізачії важливими чинниками розвитку підприємств різних галузей є також прямі іноземні інвестиції на міжнародному ринку капіталу та, зокрема, на ринку публічного розміщення акцій (IPO). Не дивлячись на наявну інвестииійну кон'юнктуру, загальна динаміка ринку IPO зростає, залучення коштів за допомогою IРО дедалі більше стає джерелом фінансування розвитку підприємств.

Ключові слова: інвестування, підприємства газової промисловості України, прямі іноземні інвестиції, первинне публічне розміщення акцій (IPO), фондовий ринок, циклічність розвитку економіки. 
Цикличность развития национальной экономики Украины четко прослежсивается на протяжении ее независимости по основным макроэкономическим показателям. $B$ статье исследованы тенденции аккумулирования и перераспределения инвестиционных ресурсов на рынке ценных бумаг в условиях иикличности развития экономики. Опыт развитых стран подтверждает, что при отсутствии благоприятного инвестииионного климата, четкой структуры субъектов и инструментов инвестирования, необходимых количественных и качественных показателей хозяйственной деятельности объектов инвестирования, невозможно достичь нужного уровня активности инвестиционных прочессов.

Выявлены особенности развития мирового фондового рынка и рынка Украины;; для эффективного функиионирования рынка цеенных бумаг в современных условиях существует проблема недостаточного уровня рыночной капитализачии предприятий реального сектора национальной экономики, потенциально открытой для инвестирования.

Проанализированы состояние и развитие процессов инвестирования предприятий газовой промышленности Украины. Вылявлено, что в условиях глобализачии важными факторами развития предприятий различных отраслей также являются прямые иностранные инвестиции на международном рынке капитала и, в частности, на рынке публичного размещения акиий (IPO). Несмотря на имеющуюся инвестииионную конъюнктуру, общая динамика рынка IPO растет, привлечения средств с помощью IPO все больше становится источником финансирования развития предприятий.

Ключевые слова: инвестирование, предприятия газовой промышленности Украины, прямые иностранные инвестиции, первичное публичное размещение акций (IPO), фондовый рынок, цикличность развития экономики.

Cyclical nature of Ukrainian national economy clearly seen over the years of independence the main macroeconomic indicators. In this article it was researched the trends of accumulation and redistribution of investment resources in the securities market in terms of cyclical economic development. The experience of developed countries confirms that in the absence of a favorable investment climate and the clear structure of investment tools, appropriate quantitative and qualitative indicators of economic activity investment targets it was impossible to achieve the desired level of activity of investment processes.

It was revealed the features of the global stock market and the stock market of Ukraine; for the effective functioning of the securities market under current conditions there is a problem of insufficient market capitalization of the real sector of the economy, potentially open for investment.

It was analyzed the state and development processes of investment enterprises Ukraine's gas industry. It was revealed that in condition of globalization the important factors of enterprises development in various industries are also foreign direct investment on international capital markets and, in particular, on public initial offering (IPO). Despite on existing investment situation, the overall dynamics of the IPO market is growing, raising funds through IPO is increasingly becoming a source of enterprises financing development.

Keywords: investment, gas industry enterprises of Ukraine, foreign direct investment, initial public offering (IPO), stock market, cyclical nature of economic development.

Вступ. В ринковій економіці довгострокове економічне зростання не буває рівномірним, оскільки воно переривається періодами економічної нестабільності. Макроекономічна рівновага $\epsilon$ динамічною, мінливою. Економічний цикл характеризується періодичним зростанням і падінням 
ділової активності та проявляється в невідповідності сукупного попиту й сукупної пропозиції, розбіжності між фактичним і потенційно можливим національним продуктом.

Криза $є$ основною фазою економічного циклу, вона $є$ його ключовою характеристикою - ii періодичне повторення надає ринковій економіці характеру циклічності. Курс акцій і інших цінних паперів на фондових біржах швидко падає; тимчасово закриваються або навіть банкрутують багато фірм, передусім дрібних (у випадку глибокої і тривалої кризи), ринкова кон'юнктура стає вкрай несприятливою. Внаслідок дії кризи поступово ліквідуються порушення макроекономічної стабільності і рівноваги між сукупним попитом і сукупною пропозицією, інвестиціями і заощадженнями, виробництвом i споживанням, тобто знову забезпечується певна пропорційність економічного розвитку, але за низького рівня сукупного попиту, неповної зайнятості виробничих ресурсів, високого безробіття.

Постановка завдання. Основними цілями дослідження є: виявлення тенденцій акумулювання та перерозподілу інвестиційних ресурсів на ринку цінних паперів в умовах циклічності розвитку економіки; виявлення особливостей розвитку світового фондового ринку; аналіз стану і розвитку процесів інвестування підприємств газової промисловості України.

Методологія. Дослідження проводились з використанням комплексного аналізу для виявлення причинно-наслідкових зв'язків між особливостями газової промисловості України, зокрема, економіко-математичного, розрахунково-аналітичного, візуально-графічного методів для аналізу фактичного стану фінансово-економічної діяльності підприємств газової промисловості та виявлення тенденцій інвестування в умовах циклічності світогосподарського розвитку економіки.

Результати дослідження. В системі економічних криз вагоме місце належить структурним кризам, що є наслідком однобічного розвитку одних галузей за рахунок інших. В умовах НТР бурхливий розвиток в нових галузях (електроніці, атомній енергетиці) та спад виробництва в старих галузях (вугільній, нафтовій, і газовій промисловості, металургії та ін.) [1].

На початку 90-х років українська економіка ввійшла в затяжну й досить глибоку кризу. Вихід з такої кризи вимагає цілеспрямованої державної політики по соціалізації ринкової економіки, зростанню доходів всіх верств населення до рівня пропозиції якісно створюваних товарів і послуг, що забезпечує рівновагу між ринковим попитом і пропозицією товарів і послуг.

Для України можливо простежити лише малі та середні цикли, через невеликий час існування незалежної держави. Обираючи в якості об'єкта дослідження циклічного розвитку економіки щорічні показники темпів приросту валового внутрішнього продукту [2] та узагальнивши їх, можна зазначити, що динаміка реального ВВП за період незалежності країни характеризувалася нерівномірним розвитком (рис. 1). 


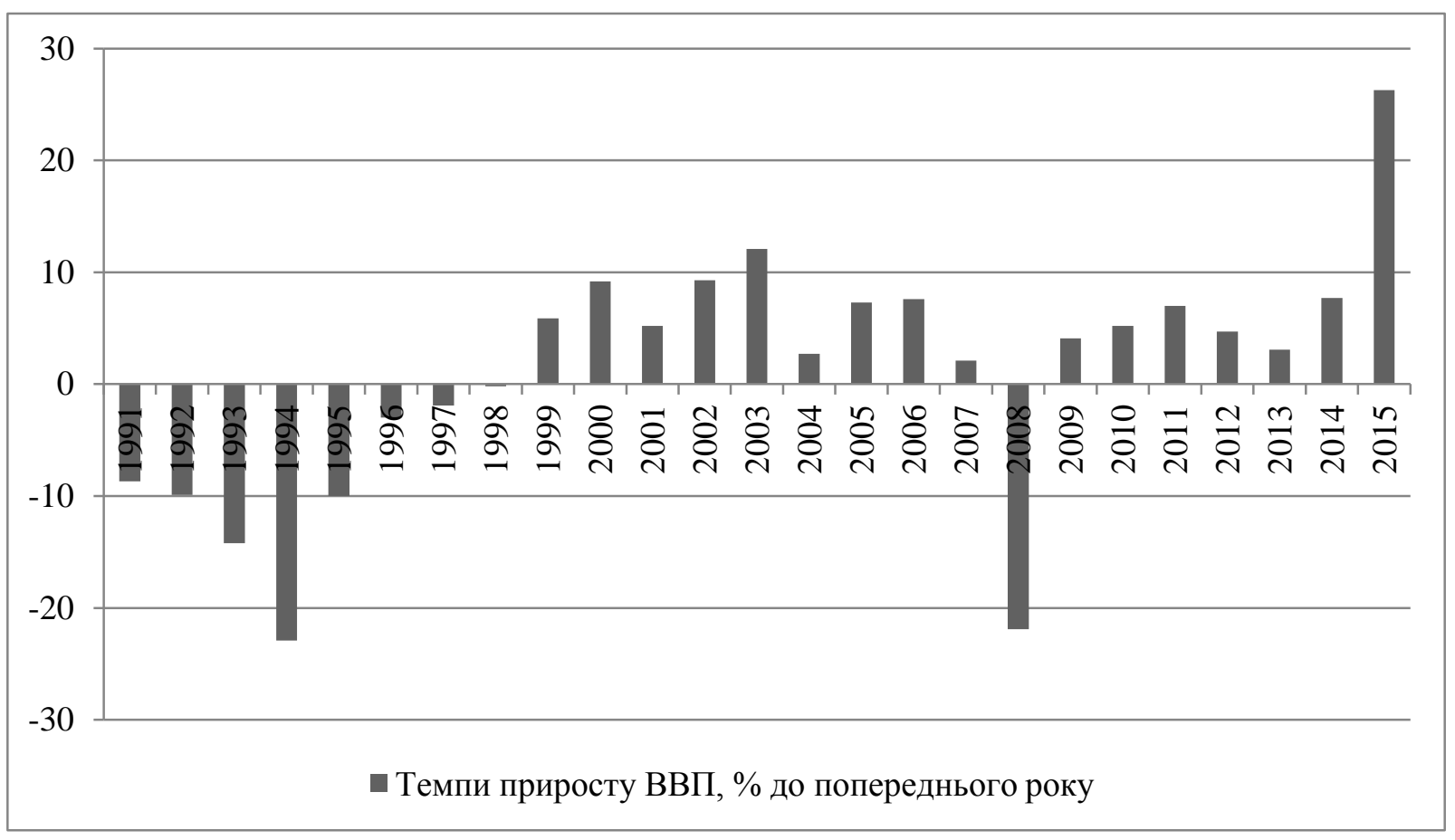

Рис. 1. Темп приросту ВВП в динаміці років Джерело: складено автором на основі [3].

Таким чином, циклічність розвитку національної економіки досить чітко простежується. В основі пошуків шляхів виведення економіки України 3 кризового стану є прагнення покращити соціально-економічну ситуацію в Україні, відновити вітчизняне виробництво, щоб створити базу для підвищення життєвого рівня населення України. Особливе місце в цьому відводиться регулюванню інвестицій та нагромадженню капіталу.

Досвід розвинутих економік підтверджує, що за умов відсутності сприятливого інвестиційного клімату, чіткої структури суб'єктів і інструментів інвестування, належних кількісних та якісних показників господарчої діяльності об'єктів інвестування неможливо досягти потрібного рівня активності інвестиційних процесів.

За 2011-2014 pр. обсяг щорічних надходжень капітальних інвестицій в підприємства газової промисловості мав коливальну динаміку (таблиця) при загальному понижувальному тренді.

Так, в 2011 р. обсяги інвестицій за всіма видами промисловості газової сфери були найбільшими. Далі простежується від'ємна динаміка, а саме: в добувній промисловості (в т. ч. газовидобувна) i розробленні кар'єрів найменший індекс інвестицій був відмічений у 2013 p. $(67,8 \%)$; в промисловості щодо постачання електроенергії, газу та кондиційованого повітря - в 2014 г. (70,3\%), а в переробній промисловості, яка енергетично залежить від газової, - в 2012 г. індекс капітальних інвестицій склав 95,6\%. 
Індекси капітальних інвестицій підприємств газової та переробної промисловості України

\begin{tabular}{|l|c|c|c|c|}
\hline \multicolumn{1}{|c|}{ Підвиди промисловості } & 2011 & 2012 & 2013 & 2014 \\
\hline $\begin{array}{l}\text { Добувна промисловість (в т.ч. газовидобувна) i } \\
\text { розроблення кар'єрів, \% }\end{array}$ & 140,3 & 129,7 & 67,8 & 74,3 \\
\hline $\begin{array}{l}\text { Постачання електроенергії, газу та кондиційованого } \\
\text { повітря, \% }\end{array}$ & 194,0 & 102,5 & 131,5 & 70,3 \\
\hline Переробна промисловість, \% & 124,6 & 95,6 & 107,7 & 79,0 \\
\hline
\end{tabular}

Джерело: складено автором на основі [3; 4].

Загалом, у 2014 р. за всіма підвидами газової промисловості простежується зниження даного показника на 66 \% у добувній промисловості у порівнянні 32011 р. і на 123\% - в промисловості щодо постачання електроенергії, газу та кондиційованого повітря. Якщо порівнювати індекси капітального інвестування відповідних галузей промисловості з переробною, то відмічається більше їх зниження відповідно на 20,4\% і 78,1\%.

Досліджуючи інвестування підприємств газової промисловості України 3 боку міжнародних інститутів таких, як Світовий банк (СБ), Свропейський банк реконструкції і розвитку (СБРР), Свропейський інвестиційний банк (СІБ) можна зазначити, що серед них за досліджуваний період з 2001 р. по 2015 р. регулярним джерелом коштів (з періодичністю два, чотири роки) виступав ЄБРР, а найбільший обсяг 300 млн. дол. у газову промисловість Україною отримано у 2015 р.

У порівнянні з 2001 р. обсяги інвестицій з СБРР мали у 2015 р. 109,3\% темпів приросту при зменшенні процентної ставки на 3,5\%, але слід зазначити негативний фактор який зменшує зростання показника - це збільшення валютного курсу дол./грн. майже у тричі. Порівнюючи індекси інвестицій ЄБРР і капітальних інвестицій в газову промисловість за видами у 2013 р. відповідно 53,3\%, 67,8\% та 131,5\%, можна відзначити, що з урахуванням валютного курсу дол./грн. інвестиційні надходження від СБРР були більш значними, ніж капітальні інвестиції.

Інші міжнародні банки інвестували у 2014 р. разом 112,16 млн. дол., при цьому основну суму інвестування надано з СІБ (111 млн. дол.) 3 незначно більшою процентною ставкою, ніж у СБ, - 0,11\%.

Підсумовуючи аналіз отриманих інвестицій від міжнародних інститутів 412,16 млн. дол. та обсяг, який необхідний для сталого розвитку підприємств газової промисловості згідно з прогнозним сценарієм КМУ - 15001 млн. дол., доходимо висновків, що інвестиції міжнародних інститутів не перекривають потрібний обсяг на 14,6 млрд. дол. [5].

В умовах глобалізації важливими чинниками розвитку підприємств різних галузей країн світу $є$ також іноземні інвестиції, які обертаються на міжнародному ринку капіталу та, зокрема, на ринку публічного розміщення 
акцій (IPO). Не дивлячись на наявну інвестиційну кон'юнктуру, загальна динаміка ринку IPO зростає, залучення коштів за допомогою IPO дедалі більше стає джерелом фінансування розвитку підприємств. Тому дослідження даного засобу залучення іноземних інвестицій представляє собою інтерес для багатьох підприємств, які планують покращувати свою інвестиційну привабливість.

За період 2008-2014 рр. українські компанії провели 59 розміщень на ринку IPO та залучили 6,2 млрд. дол., що складає 0,9\% світових обсягів за кількістю розміщень і $0,6 \%$ обсягів залучених коштів, але середній розмір угод складає 105 млрд. дол. США, що $є$ значною величиною для отримання коштів на розвиток вітчизняних підприємств [6].

В цілому, за станом на 2013 р. на Варшавській біржі (WSE) котируються акції 12 компаній з України. Тільки у 2011 р. на цю біржу вийшли 5 українських компаній: Industrial Milk Company, KSG Agro, WESTA ISIC, Ovostar Union i Coal Energy SA [7].

За період 2005-2013 рр. тенденція зміни обсягів залучених коштів українськими підприємствами за допомогою здійснення IPO носить коливальний характер (рис. 2).

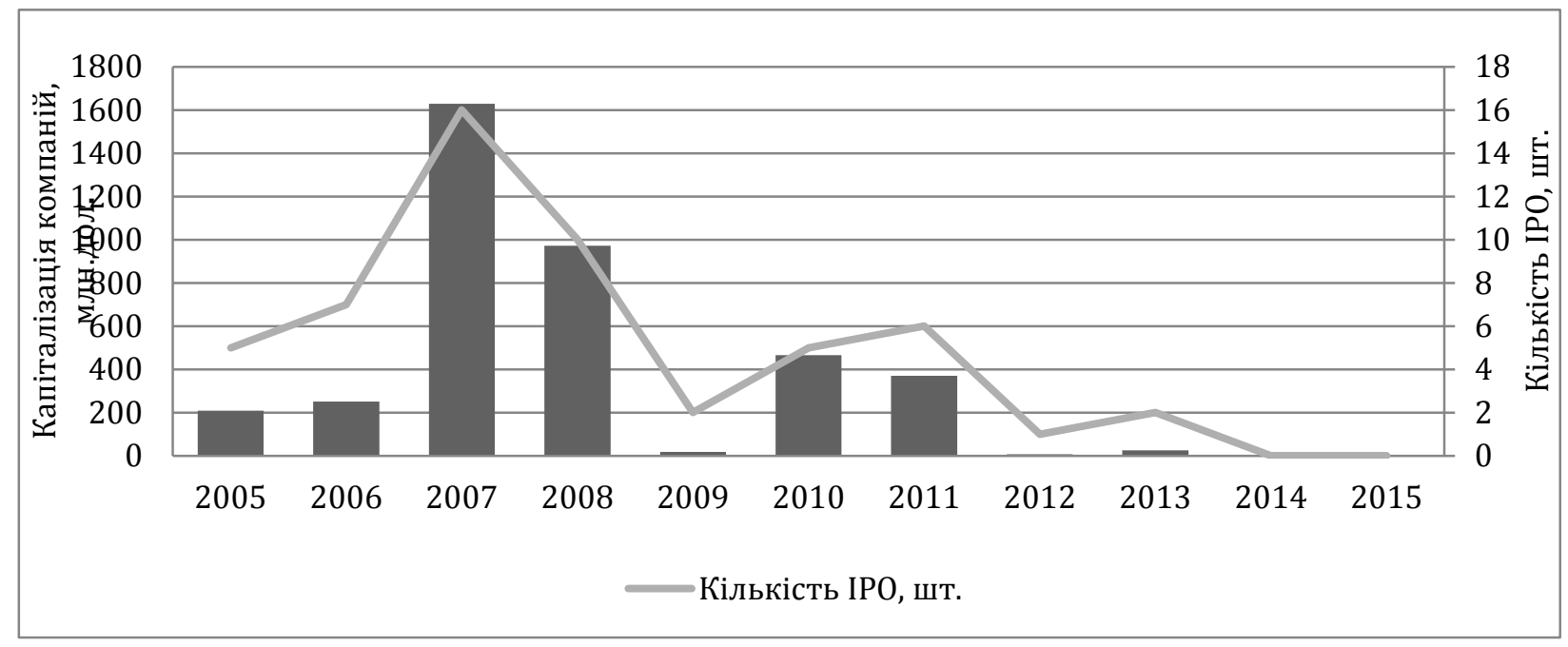

Рис. 2. Зміни обсягів залучених коштів українськими підприємствами за допомогою здійснення IPO за 2005-2013 pp.

Джерело: складено автором на основі [6].

Так, у 2007 р. обсяги залучених коштів вітчизняними підприємствами мали найвищий показник 900 млн. дол. на основі семи розміщень на ринку IPO. Низькі показники мають періоди: 2009 р. - два виходи, 2012 р. та 2013 р - один, відповідно цього отримано 17 млн. дол., 7,6 млн. дол. та 24,5 млн. дол. За останні два роки не здійснено жодного виходу на IPO вітчизняними підприємствами, хоча на 2015 р. планувалось 15 виходів. 
При розгляданні ситуації щодо залучення інвестицій засобами IPO підприємствами газової промисловості, в якості об'єктів дослідження обрані шістнадцять підприємств з країн СНД (Україна, РФ, Грузія, Казахстан), які за останні двадцять років звертались до ринку IPO з метою залучення іноземних інвестицій.

Всі зазначені підприємства за формою організації $\epsilon$ акціонерним товариствами 3 рівнем капіталізації на момент початку розміщення цінних паперів (ЦП) на IPO від 22 до 6100 млн. дол. Можна виокремити два основних періоди розміщення ЦП на IPO - це 1995-1997 pp. та 2002-2012 pp., при цьому ЦП 14 підприємств 3 16, що досліджуються, розміщені на Лондонській фондовій біржі, а інвестиційними банками найчастіше виступають швейцарський UBS та американський банківський холдинг Morgan Stanley.

Розглядаючи обсяги отриманих інвестиційних засобів слід також зазначити, що три $з$ шістнадцяти підприємств, що досліджуються, залучили від 350\% до 600\% коштів від суми загальної капіталізації підприємства на момент виходу на IPO, дев'ять підприємств - від 9\% до 44\%, чотири підприємства отримали від 50\% до майже $100 \%$ від суми капіталізації. Важливо відмітити, що зазначені обсяги інвестицій були отримані протягом одного-трьох місяців, виходячи з дат початку та кінця розміщення.

Дослідження результатів інвестиційної діяльності засобами IPO українських підприємств, можна відмітити, що загалом ними було отримано 735 млн. дол. 31995 р. по 2010 р. За період 2005-2010 рр. частка обсягів отриманих коштів газових підприємств у загальній кількості українських підприємств складає 25\% (629 млн. дол.) за три виходи на IPО від загальної кількості 28 виходів всіх підприємств України [8].

3 того часу, як відбулися останні виходи на ринок IPO підприємств газової промисловості України, минуло п'ять років, тому кошти вже засвоєні і необхідним є пошук нових інвестиційних джерел для забезпечення сталого розвитку підприємств.

Виконавши дослідження процесів зарубіжного інвестування підприємств газової промисловості засобами IPO, на прикладі країн СНД, можна зробити висновок про те, що цей засіб є достатньо результативним джерелом фінансування розвитку підприємств, але поряд 3 позитивними ефектами використання ринку IPO існує також і ряд загроз, які виникають 3 загальної характеристики такого виду зарубіжного інвестування. Тому, доцільним $є$ аналіз стану та виявлення закономірностей розвитку процесів внутрішнього інвестування підприємств газової промисловості України на прикладі ПАТ «НАК Нафтогаз» та його дочірніх та асоційованих підприємств. Аналізуючи дані фінансової звітності підприємств газової промисловості України можна побачити, що за останні сім років обсяги інвестування мали коливальні тенденції, найбільшу частку у загальному обсязі довгострокових фінансових інвестицій (ДФІ) в 2014 р. займали 
інвестиції в дочірні підприємства (93\%), серед них виділяється ДФІ ПАТ «Укргазвидобування» - 20,09\%, ПАТ «Укртрансгаз» - 61,8\% [9].

Найбільші обсяги ДФІ до 2011 р. включно припадають на асоційовані та спільні підприємства «НАК Нафтогаз», які майже втричі перевищують обсяги інвестування дочірніх підприємств.

За період 2012- 2014 рр. ситуація змінилася: ДФІ дочірніх підприємств «НАК Нафтогаз» перевищили обсяги інвестування асоційованих та спільних підприємств. Також змінилась динаміка внутрішнього інвестування 3 підвищувальної на знижувальну тенденцію, а саме, у 2014 р. порівняно 3 2012 р., темпи приросту інвестицій у дочірні підприємства скоротилися на 6\%, інші інвестиції - на 88,3\%, що спричинило зниження інвестування загалом ДФІ на 5,5\%, незважаючи на зростання обсягів інвестицій в асоційовані та спільні підприємства «НАК Нафтогаз» на 4,7\%.

Досліджуючи динаміку загальних обсягів ДФІ підприємств газової промисловості України (розрахованих у млн. дол. за курсом НБУ у звітному році), варто відмітити, що темпи росту мали позитивну динаміку лише у 2010 р. та 2012 р. (відповідно приріст склав 151,3\% та 748,7\%). За останні три роки (2014 р. у порівнянні з 2012 р.) обсяги ДФІ знизилися на 51,6\%.

Стосовно дочірніх та асоційованих підприємств «НАК Нафтогаз» у сфері виробництва газу, нафти та продуктів їх переробки, ситуація дещо краща - середні темпи приросту за останні три роки склали $17,9 \%$, але це не вплинуло на темпи зниження інвестування взагалі по підприємствам газової промисловості України. Схожа ситуація склалася і з підприємствами інших сфер промисловості, а саме: транспортування нафти та газу, оптової та роздрібної торгівлі газу. Загальні середні темпи приросту залучених інвестицій склали 19,4\%, але вони також не сприяли позитивній динаміці інвестування підприємств газової промисловості.

Підсумовуючи проведений аналіз довгострокового інвестування підприємств газової промисловості, які входять до корпорації ПАТ «НАК Нафтогаз», можна відмітити, що станом на 2014 р. отримано інвестицій на суму 139,7 млрд. грн., що майже у п'ять разів менше прогнозної необхідної величини, яку визначено КМУ за базовим прогнозним сценарієм (120 млрд. грн.) [9].

Узагальнюючи дослідження процесів інвестування підприємств газової промисловості Україні, необхідно відзначити не лише їх недостатні обсяги для подальшого сталого розвитку, але й наявність негативних очікувань промисловців галузі. Так, за даними опитувань Держкомстату України [10] на основі посилення впливу таких стримуючих виробництво факторів, як недосконале законодавство, високі тарифи природних монополій, низький платоспроможний попит на продукцію та високі податки, не передбачається поліпшення фінансово-економічного стану підприємств промисловості (рис. 3). Фактор фінансових обмежень назвали майже $45 \%$ респондентів, тому, 
наряду 3 фактором недостатнього попиту, можна зазначити, що в країні склалися несприятливі умови для фінансової стабільності підприємств.

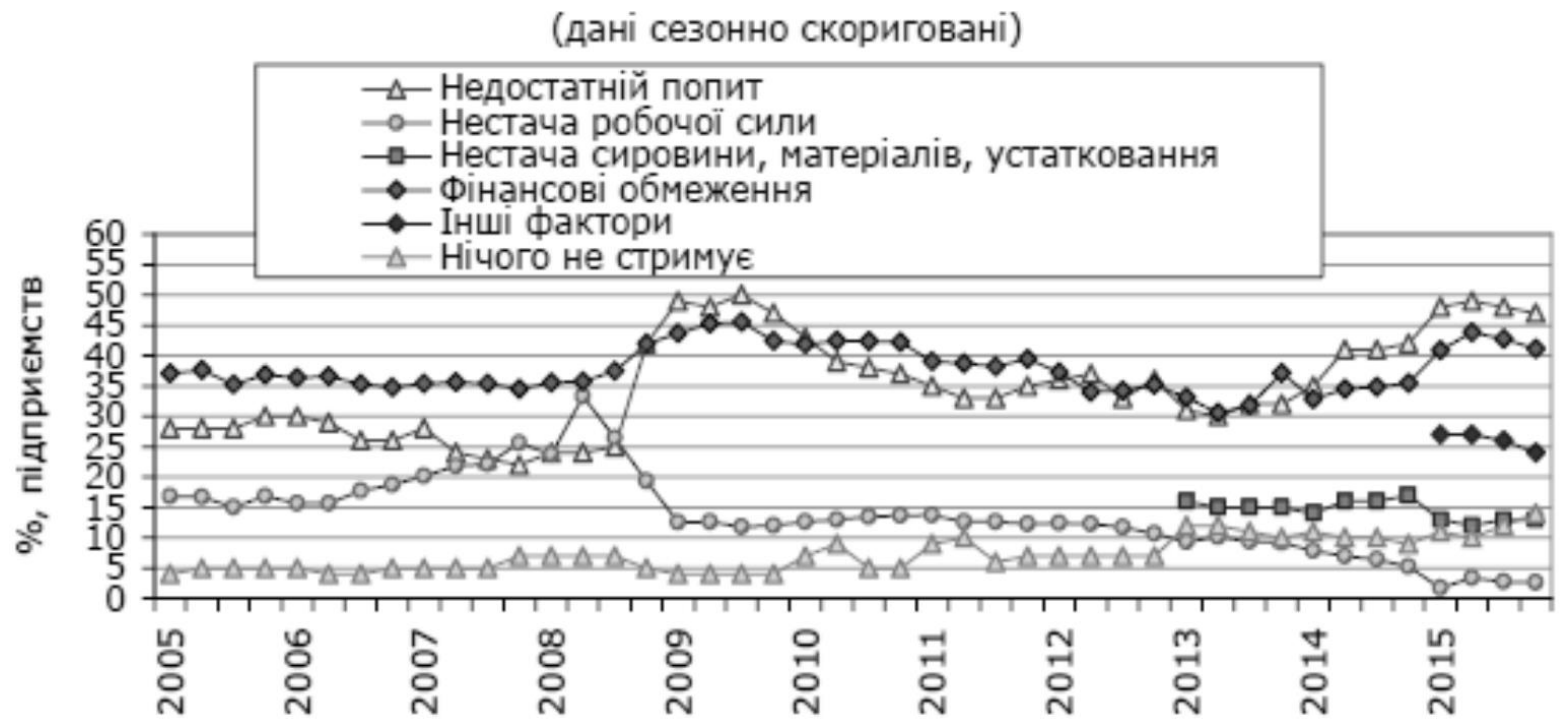

Рис. 3. Фактори, які стримують виробництво в України за опитуванням респондентів-промисловців

Джерело: складено автором на основі [3].

Очікування респондентів відносно газової промисловості мають найбільш песимістичний характер: при одному 3 найменших обсягів капітальних інвестицій у 2014 р. очікується падіння їх обсягів у 2015 р. на $36 \%$ у газодобувній промисловості та на $16 \%$ у сфері постачання газу.

Таким чином, будучи в цілому перспективною, газова промисловість України функціонує в умовах загострення фінансових проблем. В такому середовищі підприємствам неможливо забезпечити результативну діяльність та розвиток без активізації інвестиційної діяльності, що грунтується не лише на загальному «оздоровленні» економіки країни, але й більшою мірою за умов поліпшення інвестиційної привабливості саме підприємств газової промисловості.

Для ефективного функціонування ринку цінних паперів в сучасних умовах існує проблема недостатнього рівня ринкової капіталізації підприємств реального сектора національної економіки, потенційно відкритої для інвестування.

Оцінка рівня розвитку фондового ринку України як «еmerging markets» (високоризикований ринок) міжнародними організаціями знижує інтерес потенціальних інвесторів до вітчизняних об‘єктів інвестування, що, у свою чергу, не сприяє надходженню до реального сектора національної економіки портфельних інвестицій, які мають переваги перед іншими видами інвестування (наприклад, прямими іноземними інвестиціями) [10]. 
3 огляду на це, першими заходами щодо розвитку фондового ринку України повинне стати підвищення якості ресурсної бази підприємствемітентів, що позитивно позначиться на рівні їх потенціальної ринкової капіталізації на національних і міжнародних фондових майданчиках. Для їх реалізації необхідно подолати депресію ресурсної бази національної економіки за рахунок послідовного реформування ії балансової системи [11], що, у свою чергу, забезпечить підвищення інтересу потенціальних інвесторів до вітчизняного фондового ринку, а також зміцнить його конкурентоспроможні позиції на міжнародних фондових ринках в умовах сучасної фінансово-економічної кризи.

Висновки. В економічній ситуації, що склалася в Україні, розвиток ринку цінних паперів, за допомогою якого можуть бути забезпечені умови для залучення інвестицій на підприємства, слід розглядати як один 3 реальних шляхів подолання кризового занепаду i направлення значних фінансових ресурсів в умовах циклічності світо господарського розвитку. Тобто, використання фондового ринку як механізму переміщення коштів від інвесторів до емітентів сприятиме ринковому перерозподілу капіталів і направленню їх до сфер пріоритетного використання.

Вихід на світовий фінансовий ринок розширить можливості українських підприємств в отриманні необхідних в умовах кризи фінансових ресурсів, і таким чином, сприятиме розвитку промислових підприємств $i$, як наслідок, підвищенню життєвого рівня населення. Разом 3 тим, варто враховувати циклічний розвиток як світової, так і національної економіки у тому, що міжнародний рух капіталу підпорядкований власним закономірностям, його напрям та інтенсивність можуть суперечити в той чи інший час інтересам національної економіки та політиці уряду.

\section{Література:}

1. Клименко Г.Н., Нестеренко В.П. Основи економічної теорії: політичний аспект / Г.Н. Клименко, В.П. Нестеренко. - Київ: «Вища Школа», 2004. - 743 с.

2. Офіційний веб-сайт Національного Банку України. [Електронний ресурс] - Режим доступу: http://www.bank.gov.ua

3. Офіційний веб-сайт Державної служби статистики України. [Електронний ресурс] Режим доступу: http://www.ukrstat.gov.ua/

4. Офіційний веб-сайт Міністерства енергетики та вугільної промисловості України. [Електронний ресурс] - Режим доступу: http://mpe.kmu.gov.ua/

5. Офіційний веб-сайт European Bank for Reconstruction and Development. [Електронний pecypc] - Режим доступу: http://www.ebrd.com/

6. Офіційний веб-сайт IPO-конгресу. [Електронний ресурс] - Режим доступу: http://www.ipocongress.ru/

7. Офіційний веб-сайт журналу Forbes Украина. [Електронний ресурс] - Режим доступу: http://forbes.net.ua/

8. Офіційний веб-сайт Інформаційно-аналітичного порталу PREQVECA. [Електронний pecypc] - Режим доступу: http://www.preqveca.ru/placements/ 
9. Офіційний веб-сайт НАК «НАФТОГАЗ». [Електронний ресурс] - Режим доступу: http://www.naftogaz.com/www/3/nakweb.nsf/

10. Гаршина О.К., Волошина Е.А. Развивающиеся фондовые рынки: сущность и рейтинги / О.К. Гаршина, Е.А. Волошина // Актуальні проблеми економіки. - 2006. №12 (66). - C.22-30.

11. Дергачова В.В. Міжнародна конкурентоспроможність національної економіки в контексті забезпечення економічного зростання: монографія. - Д.: ДонДЕУТ, 2006. $-392 \mathrm{c}$. 